\title{
BAHAYA NARKOBA
}

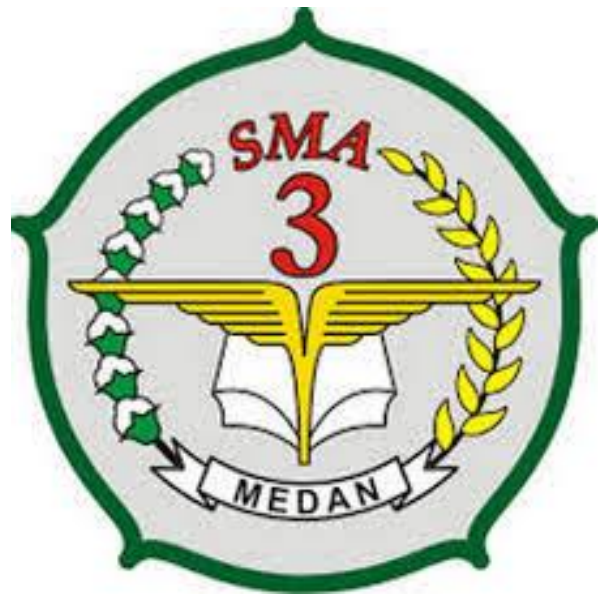

\section{DISUSUN OLEH :}

NAJWA SHEILA HAIFA

X MIA 2

SMA NEGERI 3 MEDAN

TAHUN AJARAN 2019/2020 


\section{KATA PENGANTAR}

Puji syukur kehadirat Allah SWT yang telah memberikan rahmat dan hidayah-Nya sehingga saya dapat menyelesaikan tugas makalah yang berjudul Bahaya Narkoba ini tepat pada waktunya.

Adapun tujuan dari penulisan dari makalah ini adalah untuk memenuhi tugas Pendidikan Jasmani Olahraga dan Kesehatan. Selain itu, makalah ini juga bertujuan untuk menambah wawasan tentang Bahaya Narkoba bagi para pembaca dan juga bagi penulis.

Saya mengucapkan terima kasih kepada semua pihak yang telah membagi sebagian pengetahuannya sehingga saya dapat menyelesaikan makalah ini.

Saya menyadari, makalah yang saya tulis ini masih jauh dari kata sempurna. Oleh karena itu, kritik dan saran yang membangun akan saya nantikan demi kesempurnaan makalah ini.

Medan, 20 Mei 2020

Najwa Sheila Haifa 


\section{BAB I \\ PENDAHULUAN}

\section{A. Latar Belakang}

Narkoba merupakan singkatan dari Narkotika, Psikotropika dan Bahan Adiktif lainnya. Terminologi narkoba familiar digunakan oleh aparat penegak hukum; seperti polisi (termasuk didalamnya Badan Narkotika Nasional), jaksa, hakim dan petugas Pemasyarakatan. Selain narkoba, sebutan lain yang menunjuk pada ketiga zat tersebut adalah Napza yaitu Narkotika, Psikotropika dan Zat Adiktif. Istilah napza biasanya lebih banyak dipakai oleh para praktisi kesehatan dan rehabilitasi. Akan tetapi pada intinya pemaknaan dari kedua istilah tersebut tetap merujuk pada tiga jenis zat yang sama.

Menurut UU No.22 Tahun 1997 tentang Narkotika disebutkan pengertian Narkotika adalah Narkotika adalah "zat atau obat yang berasal dari tanaman atau bukan tanaman baik sintetis maupun semi sintetis yang dapat menyebabkan penurunan atau perubahan kesadaran, hilangnya rasa, mengurangi sampai menghilangkan rasa nyeri, dan dapat menimbulkan ketergantungan".

Sebenarnya narkoba itu obat legal yang digukan dalam dunia kedokteran, namun dewasa ini narkoba banyak disalahgunakan. Bahkan kalangan muda tidak sedikit yang menggunakan narkoba. Banyak dari mereka yang menggunakan narkoba dengan alasan untuk kesenangan batin, namun sayangnya tidak banyak yang mengetahui bahaya narkoba.

\section{B. Rumusan Masalah}

1. Apa pengertian narkoba?

2. Ada berapa jenis narkoba?

3. Apa bahaya narkoba?

4. Bagimana cara mengatasinya?

\section{Tujuan}

1. Sebagai pengetahuan bagi para remaja tentang bahasa narkoba bagi dirinya. 
2. Sebagai sebuah referinsi sehingga para remaja bisa mengerti tentang jenis- jenis narkoba.

\section{Manfaat}

Makalah ini diharapkan dapat bermanfaat yang antara lain :

1) Mengetahui pengertian dari Narkoba

2) Mengetahui jenis jenis dari Narkoba

3) Mengetahui bahaya Narkoba

4) Mengetahui cara pencegahan Narkoba 


\section{BAB II \\ PEMBAHASAN}

\section{A. Pengertian Narkoba}

Narkoba merupakan singkatan dari Narkotika, Psikotropika dan Bahan Adiktif lainnya. Terminologi narkoba familiar digunakan oleh aparat penegak hukum; seperti polisi (termasuk didalamnya Badan Narkotika Nasional), jaksa, hakim dan petugas Pemasyarakatan. Selain narkoba, sebutan lain yang menunjuk pada ketiga zat tersebut adalah Napza yaitu Narkotika, Psikotropika dan Zat Adiktif. Istilah napza biasanya lebih banyak dipakai oleh para praktisi kesehatan dan rehabilitasi. Akan tetapi pada intinya pemaknaan dari kedua istilah tersebut tetap merujuk pada tiga jenis zat yang sama.

Menurut UU No.22 Tahun 1997 tentang Narkotika disebutkan pengertian Narkotika adalah Narkotika adalah "zat atau obat yang berasal dari tanaman atau bukan tanaman baik sintetis maupun semi sintetis yang dapat menyebabkan penurunan atau perubahan kesadaran, hilangnya rasa, mengurangi sampai menghilangkan rasa nyeri, dan dapat menimbulkan ketergantungan”.

Psikotropika adalah "zat atau obat, baik alamiah maupun sintetis bukan narkotika, yang berkhasiat psikoaktif melalui pengaruh selektif pada susunan saraf pusat yang menyebabkan perubahan khas pada aktivitas mental dan perilaku". Bahan adiktif lainnya adalah "zat atau bahan lain bukan narkotika dan psikotropika yang berpengaruh pada kerja otak dan dapat menimbulkan ketergantungan”.

Meskipun demikian, penting kiranya diketahui bahwa tidak semua jenis narkotika dan psikotropika dilarang penggunaannya. Karena cukup banyak pula narkotika dan psikotropika yang memiliki manfaat besar di bidang kedokteran dan untuk kepentingan pengembangan pengetahuan. Menurut UU No.22 Tahun 1997 dan UU No.5 Tahun 1997, narkotika dan psikotropika yang termasuk dalam Golongan I merupakan jenis zat yang dikategorikan illegal. Akibat dari status illegalnya tersebut, siapapun yang memiliki, memproduksi, menggunakan, mendistribusikan dan / atau mengedarkan narkotika dan psikotropika Golongan I dapat dikenakan pidana sesuai dengan ketentuan hukum yang berlaku. 


\section{B. Jenis-Jenis Narkoba}

- Candu

Getah tanaman Papaver Somniferum didapat dengan menyadap (menggores) buah yang hendak masak. Getah yang keluar berwarna putih dan dinamai "Lates". Getah ini dibiarkan mengering pada permukaan buah sehingga berwarna coklat kehitaman dan sesudah diolah akan menjadi suatu adonan yang menyerupai aspal lunak. Inilah yang dinamakan candu mentah atau candu kasar. Candu kasar mengandung bermacam-macam zat-zat aktif yang sering disalahgunakan. Candu masak warnanya coklat tua atau coklat kehitaman. Diperjual belikan dalam kemasan kotak kaleng dengan berbagai macam cap, antara lain ular, tengkorak,burung elang, bola dunia, cap 999, cap anjing, dsb. Pemakaiannya dengan cara dihisap.

- Morfin

Morfin adalah hasil olahan dari opium/candu mentah. Morfin merupaakan alkaloida utama dari opium ( C17H19NO3 ) . Morfin rasanya pahit, berbentuk tepung halus berwarna putih atau dalam bentuk cairan berwarna. Pemakaiannya dengan cara dihisap dan disuntikkan.

- Heroin ( putaw ) Heroin mempunyai kekuatan yang dua kali lebih kuat dari morfin dan merupakan jenis opiat yang paling sering disalahgunakan orang di Indonesia pada akhir akhir ini . Heroin, yang secara farmakologis mirip dengan morfin menyebabkan orang menjadi mengantuk dan perubahan mood yang tidak menentu. Walaupun pembuatan, penjualan dan pemilikan heroin adalah ilegal, tetapi diusahakan heroin tetap tersedia bagi pasien dengan penyakit kanker terminal karena efek analgesik dan euforik-nya yang baik.

- Codein

Codein termasuk garam / turunan dari opium / candu. Efek codein lebih lemah daripada heroin, dan potensinya untuk menimbulkan ketergantungaan rendah. Biasanya dijual dalam bentuk pil atau cairan jernih. Cara pemakaiannya ditelan dan disuntikkan.

- Demerol

Nama lain dari Demerol adalah pethidina. Pemakaiannya dapat ditelan atau dengan suntikan. Demerol dijual dalam bentuk pil dan cairan tidak berwarna.

- Methadon 
Saat ini Methadone banyak digunakanorang dalam pengobatan ketergantungan opioid. Antagonis opioid telah dibuat untuk mengobati overdosis opioid dan ketergantungan opioid. Sejumlah besar narkotik sintetik (opioid) telah dibuat, termasuk meperidine (Demerol), methadone (Dolphine), pentazocine (Talwin), dan propocyphene (Darvon). Saat ini Methadone banyak digunakan orang dalam pengobatan ketergantungan opioid. Antagonis opioid telah dibuat untuk mengobati overdosis opioid dan ketergantungan opioid. Kelas obat tersebut adalah nalaxone (Narcan), naltrxone (Trexan), nalorphine, levalorphane, dan apomorphine. Sejumlah senyawa dengan aktivitas campuran agonis dan antagonis telah disintesis, dan senyawa tersebut adalah pentazocine, butorphanol (Stadol), dan buprenorphine (Buprenex). Beberapa penelitian telah menemukan bahwa buprenorphine adalah suatu pengobatan yang efektif untuk ketergantungan opioid. Nama popoler jenis opioid : putauw, etep, PT, putih.

\section{Faktor yang Mendorong}

Motivasi dalam penyalahgunaan zat dan narkotika ternyata menyangkut motivasi yang berhubungan dengan keadaan individu (motivasi individual) yang mengenai aspek fisik, emosional, mental-intelektual dan interpersonal.

Di samping adanya motivasi individu yang menimbulkan suatu tindakan penyalahgunaan zat, masih ada faktor lain yang mempunyai hubungan erat dengan kondisi penyalahgunaan zat yaitu faktor sosiokultural seperti di bawah ini; dan ini merupakan suasana hati menekan yang mendalam dalam diri remaja; antara lain:

- Perpecahan unit keluarga misalnya perceraian, keluarga yang berpindah-pindah, orang tua yang tidak ada/jarang di rumah dan sebagainya.

- Pengaruh media massa misalnya iklan mengenai obat-obatan dan zat.

- Perubahan teknologi yang cepat.

- Kaburnya nilai-nilai dan sistem agama serta mencairnya standar moral; (hal ini berarti perlu pembinaan Budi Pekerti - Akhlaq)

- Meningkatnya waktu menganggur.

- Ketidakseimbangan keadaan ekonomi misalnya kemiskinan, perbedaan ekonomi etno rasial, kemewahan yang membosankan dan sebagainya. 
- Menjadi manusia untuk orang lain.

\section{Bahaya Narkoba}

\section{a. Menurut Efeknya}

- Halusinogen, efek dari narkoba bisa mengakibatkan bila dikonsumsi dalam sekian dosis tertentu dapat mengakibatkan seseorang menjadi ber-halusinasi dengan melihat suatu hal/benda yang sebenarnya tidak ada / tidak nyata contohnya kokain \& LSD

- Stimulan, efek dari narkoba yang bisa mengakibatkan kerja organ tubuh seperti jantung dan otak bekerja lebih cepat dari kerja biasanya sehingga mengakibatkan seseorang lebih bertenaga untuk sementara waktu, dan cenderung membuat seorang pengguna lebih senang dan gembira untuk sementara waktu

- Depresan, efek dari narkoba yang bisa menekan sistem syaraf pusat dan mengurangi aktivitas fungsional tubuh, sehingga pemakai merasa tenang bahkan bisa membuat pemakai tidur dan tidak sadarkan diri. Contohnya putaw

- Adiktif, Seseorang yang sudah mengkonsumsi narkoba biasanya akan ingin dan ingin lagi karena zat tertentu dalam narkoba mengakibatkan seseorang cenderung bersifat pasif, karena secara tidak langsung narkoba memutuskan syaraf-syaraf dalam otak,contohnya ganja , heroin , putaw

- Jika terlalu lama dan sudah ketergantungan narkoba maka lambat laun organ dalam tubuh akan rusak dan jika sudah melebihi takaran maka pengguna itu akan overdosis dan akhirnya kematian

Adapun bahaya narkoba berdasarkan jenisnya adalah sebagai berikut:

1. Opioid:

- depresi berat

- apatis

- rasa lelah berlebihan

- malas bergerak 
- banyak tidur

- gugup

- gelisah

- selalu merasa curiga

- denyut jantung bertambah cepat

- rasa gembira berlebihan

- banyak bicara namun cadel

- rasa harga diri meningkat

- kejang-kejang

- pupil mata mengecil

- tekanan darah meningkat

- berkeringat dingin

- mual hingga muntah

- luka pada sekat rongga hidung

- kehilangan nafsu makan

- turunnya berat badan

2. Kokain

- denyut jantung bertambah cepat

- gelisah

- rasa gembira berlebihan

- rasa harga diri meningkat

- banyak bicara

- kejang-kejang

- pupil mata melebar

- berkeringat dingin

- mual hingga muntah

- mudah berkelahi

- pendarahan pada otak

- penyumbatan pembuluh darah

- pergerakan mata tidak terkendali

- kekakuan otot leher 
3. Ganja

- mata sembab

- kantung mata terlihat bengkak, merah, dan berair

- sering melamun

- pendengaran terganggu

- selalu tertawa

- terkadang cepat marah

- tidak bergairah

- gelisah

- dehidrasi

- tulang gigi keropos

- liver

- saraf otak dan saraf mata rusak

- skizofrenia

4. Ectasy

- enerjik tapi matanya sayu dan wajahnya pucat

- berkeringat

- sulit tidur

- kerusakan saraf otak

- dehidrasi

- gangguan liver

- tulang dan gigi keropos

- tidak nafsu makan

- saraf mata rusak

5. Shabu-shabu:

- enerjik

- paranoid

- sulit tidur

- sulit berfikir

- kerusakan saraf otak, terutama saraf pengendali pernafasan hingga merasa sesak nafas - banyak bicara 
- denyut jantung bertambah cepat

- pendarahan otak

- shock pada pembuluh darah jantung yang akan berujung pada kematian.

6. Benzodiazepin:

- berjalan sempoyongan

- wajah kemerahan

- banyak bicara tapi cadel

- mudah marah

- konsentrasi terganggu

- kerusakan organ-organ tubuh terutama otak

Jadi dapat disimpulkan apabila narkoba dikonsumsi oleh:

a. Remaja

Masa remaja merupakan suatu fase perkembangan antara masa anak-anak dan masa dewasa. Perkembangan seseorang dalam masa anak-anak dan remaja akan membentuk perkembangan diri orang tersebut di masa dewasa. Karena itulah bila masa anak-anak dan remaja rusak karena narkoba, maka suram atau bahkan hancurlah masa depannya.

Pada masa remaja, justru keinginan untuk mencoba-coba, mengikuti trend dan gaya hidup, serta bersenang-senang besar sekali. Walaupun semua kecenderungan itu wajar-wajar saja, tetapi hal itu bisa juga memudahkan remaja untuk terdorong menyalahgunakan narkoba. Data menunjukkan bahwa jumlah pengguna narkoba yang paling banyak adalah kelompok usia remaja.

Masalah menjadi lebih gawat lagi bila karena penggunaan narkoba, para remaja tertular dan menularkan HIV/AIDS di kalangan remaja. Hal ini telah terbukti dari pemakaian narkoba melalui jarum suntik secara bergantian. Bangsa ini akan kehilangan remaja yang sangat banyak akibat penyalahgunaan narkoba dan merebaknya HIV/AIDS. Kehilangan remaja sama dengan kehilangan sumber daya manusia bagi bangsa.

b. Pelajar 
Di Indonesia, pencandu narkoba ini perkembangannya semakin pesat. Para pencandu narkoba itu pada umumnya berusia antara 11 sampai 24 tahun. Artinya usia tersebut ialah usia produktif atau usia pelajar. Pada awalnya, pelajar yang mengonsumsi narkoba biasanya diawali dengan perkenalannya dengan rokok.

Karena kebiasaan merokok ini sepertinya sudah menjadi hal yang wajar di kalangan pelajar saat ini. Dari kebiasaan inilah, pergaulan terus meningkat, apalagi ketika pelajar tersebut bergabung ke dalam lingkungan orang-orang yang sudah menjadi pencandu narkoba. Awalnya mencoba, lalu kemudian mengalami ketergantungan.

Dampak negatif penyalahgunaan narkoba terhadap anak atau remaja adalah sebagai berikut:

- Perubahan dalam sikap, perangai dan kepribadian

- Sering membolos, menurunnya kedisiplinan dan nilai-nilai pelajaran

- Menjadi mudah tersinggung dan cepat marah

- Sering menguap, mengantuk, dan malas

- Tidak memedulikan kesehatan diri

- Suka mencuri untuk membeli narkoba

\section{E. Penyelesaian/Solusi}

Banyak yang masih bisa dilakukan untuk mencegah remaja menyalahgunakan narkoba dan membantu remaja yang sudah terjerumus penyalahgunaan narkoba. Ada tiga tingkat intervensi, yaitu :

1. Primer, sebelum penyalahgunaan terjadi, biasanya dalam bentuk pendidikan, penyebaran informasi mengenai bahaya narkoba, pendekatan melalui keluarga, dll. Instansi pemerintah, seperti halnya BKKBN, lebih banyak berperan pada tahap intervensi ini. kegiatan dilakukan seputar pemberian informasi melalui berbagai bentuk materi KIE yang ditujukan kepada remaja langsung dan keluarga.

2. Sekunder, pada saat penggunaan sudah terjadi dan diperlukan upaya penyembuhan (treatment). Fase ini meliputi: Fase penerimaan awal (initialintake)antara $1-3$ hari dengan melakukan pemeriksaan fisik dan mental, dan Fase detoksifikasi dan terapi komplikasi medik, antara $1-3$ minggu untuk melakukan pengurangan ketergantungan bahan-bahan adiktif secara bertahap.

3. Tersier, yaitu upaya untuk merehabilitasi merekayang sudah memakai dan dalam proses penyembuhan. Tahap ini biasanya terdiri atas Fase stabilisasi, antara 3-12 bulan, untuk mempersiapkan pengguna kembali ke masyarakat, dan Fase sosialiasi dalam 
masyarakat, agar mantan penyalahguna narkoba mampu mengembangkan kehidupan yang bermakna di masyarakat. Tahap ini biasanya berupa kegiatan konseling, membuat kelompok-kelompok dukungan, mengembangkan kegiatan alternatif, dll. 


\section{BAB III \\ PENUTUP}

\section{A. Kesimpulan}

Dari makalah di atas bisa ditark kesimpulan bahwa :

1) Narkoba adalah barang yang sangat berbahaya dan bisa merusak susunan syaraf yang bisa merubah sebuah kepribadian seseorang menjadi semakin buruk.

2) Narkoba adalah sumber dari tindakan kriminalitas yang bisa merusak norma dan ketentraman umum.

3) Menimbulkan dampak negatif yang mempengaruhi pada tubuh baik secara fisik maupun psikologis. 


\section{DAFTAR PUSTAKA}

- Effendi, Luqman, 2008. Modul Dasar-Dasar Sosiologi\&Sosiologi KesehatanI. Jakarta: PSKM FKK UMJ.

- Kartono, Kartini, 1992. Patologi II Kenakalan Remaja. Jakarta: Rajawali.

- Mangku, Made Pastika, Mudji Waluyo, Arief Sumarwoto, dan Ulani Yunus, 2007. pecegahan Narkoba Sejak Usia Dini. Jakarta: Badan Narkotika Nasional Republik Indonesia.

- Shadily, Hassan, 1993. Sosiologi Untuk Masyarakat Indonesia. Jakarta: PT RINEKA CIPTA.

- Soekanto, Suryono, 2006. Sosiologi Suatu Pengantar. Jakarta: PT Raja Grafindo Persuda

- Sofyan, Ahmadi, 2007. Narkoba Mengincar Anak Anda Panduan bagi Orang tua, Guru, dan Badan Narkotika dalam Penanggulangan Bahaya Narkoba di Kalangan Remaja. Jakarta: Prestasi Pustaka Publisher.

- Sudarman, Momon, 2008. Sosiologi Untuk Kesehatan. Jakarta: Salemba Medika.

- Syani, Abdul, 1995. Sosiologi dan Perubahan Masyarakat. PT DUNIA PUSTAKA JAYA. 